\title{
PEMISAHAN CAMPURAN ASAM LEMAK DENGAN METODE KROMATOGRAFI KOLOM MENGGUNAKAN FASA DIAM BERBAHAN DASAR ABU SEKAM PADI
}

\author{
Endang Widiastuti dan Eti Prihantini \\ Jurusan Teknik Kimia-Politeknik Negeri Bandung \\ Jl. Gegerkalong Hilir - Ds. Ciwaruga Bandung 40012 \\ Email: endwidy@yahoo.com
}

\begin{abstract}
ABSTRAK
Indonesia sebagai negara agraris mempunyai banyak jenis tumbuhan penghasil minyak nabati yang mengandung asam lemak jenuh dan tidak jenuh. Asam lemak tersebut dimanfaatkan oleh industri makanan dan obat-obatan. Asam-asam lemak yang masih berupa campuran perlu dipisahkan, salah satunya dengan metoda kromatografi ion perak. Prinsip dari metode ini adalah berdasarkan perbedaan afinitas antara asam lemak dengan fasa diam dan fasa gerak. Salah satu faktor yang menentukan tingkat keberhasilan proses pemisahan pada kromatografi adalah fasa diam.

Pada penelitian ini, fasa diam diperoleh dengan memanfaatkan silika yang terkandung dalam abu sekam padi. Silika yang diperoleh berbentuk sol yang kemudian dimodifikasi dengan AgNO3 menggunakan senyawa pendukung yang divariasikan jenisnya yaitu amino propil trimetoksisilan (APTS) dan kitosan. Kedua jenis silika yang dimodifikasi kemudian dianalisis kadar ion Ag yang terikat secara titrasi potensiometri, Selanjutnya silika tersebut digunakan sebagai fasa diam pada kolom kromatografi padat-cair, untuk memisahkan campuran asam oleat, asam palmitat dan asam stearat yang telah dimetilasi. Eluen yang digunakan pada pemisahan adalah campuran kloroformmetanol atau benzene-metanol yang komposisinya divariasikan antara 100:0 hingga 90:10. Hasil pemisahan dari kolom tersebut dianalisis menggunakan kromatografi gas (GC). Dari penelitian ini, ion Ag yang terikat pada silika-kitosan adalah $87 \%$ sedangkan silika-APTS adalah $89 \%$ karena perbedaannya tidak signifikan maka sebagai fasa diam pada kolom kromatografi digunakan silika kitosan. Berdasarkan hasil analisis secara SEM dan EDS, silika tersebut mengandung SiO2 69\% dan Ag2O 18\%. Hasil pemisahan dari kolom kromatografi menunjukan bahwa campuran metil oleat dan metil palmitat dapat dielusi dengan pelarut kloroform - methanol, sedangkan campuran metil palmitat dan metil stearat dielusi dengan pelarut benzena-metanol. Kedua jenis eleun tersebut mempunyai perbandingan komposisi yang sama yaitu 97:3.
\end{abstract}

\section{PENDAHULUAN}

Pada saat ini seiring dengan meningkatnya kesadaran masyarakat terhadap kesehatan, pemanfaatan asam lemak oleh industri makanan dan obat-obatan telah berkembang sangat pesat. Asam lemak banyak terkandung dalam minyak nabati maupun hewani yang mempunyai karakteristik senyawa karbon rantai panjang. Terdapat 2 (dua) jenis asam lemak, yaitu asam lemak jenuh seperti asam palmitat dan stearat serta asam lemak tak jenuh, seperti asam oleat dan linoleat. Asam-asam tersebut seringkali terdapat dalam bentuk asam lemak bebas dan senyawa ester, yang diperlukan oleh manusia tetapi tidak dapat disintesis dalam tubuh. Dengan demikian perlu dikembangkan metode pemisahan dan pemurnian asam lemak dari minyak nabati atau hewani.

Ada beberapa metode pemisahan dan pemurnian asam lemak, salah satunya kromatografi. Metode ini menggunakan fasa diam sebagai media pemisahan dan fasa gerak sebagai eluennya. Tingkat keberhasilan metode tersebut diantaranya dipengaruhi oleh mekanisme pemisahan dan jenis fasa diam. Pada penelitian ini digunakan fasa diam berbahan dasar sekam padi dengan mekanisme adsopsi dan partisi. 
Indonesia sebagai negara agraris yang mayoritas makanan pokok penduduknya adalah beras, tidak sulit menemukan sekam padi sebagai limbah dari penggilingan beras. Diketahui kadar silika dalam sekam padi dapat mencapai 90\%. Jika sekam padi tersebut dilebur pada suhu lebih dari $650^{\circ} \mathrm{C}$, dapat menghasilkan hingga 97\%, dengan struktur amorf dan bersifat adsorben (K.G,Mansaray, Energy Source 19, 1997).

Kromatografi merupakan metode pemisahan yang sangat baik dan efektif untuk senyawa-senyawa yang mempunyai kemiripan sifat fisik, misal titik didihnya. Metode kromatografi lapis tipis dan kromatografi kinerja tinggi untuk menganalisis campuran asam lemak jenuh dan tidak jenuh adalah kromatografi ion perak yaitu menggunakan fasa diam yang mengandung silika dan ion perak. Ion perak tersebut akan mengikat asam lemak tak jenuh karena mempunyai ikatan rangkap, sedangkan asam lemak jenuh yang tidak mempunyai ikatan rangkap, tidak akan berinteraksi dengan fasa diam. Berdasarkan prinsip tersebut selanjutnya diterapkan pada metoda kromatografi kolom. Metode tersebut tidak hanya digunakan untuk skala laboratorium tetapi dapat dikembangkan untuk skala yang lebih besar. Salah satu kendala metode kromatografi dalam skala besar adalah ketersediaan fasa diam baik dari segi kuantitas maupun harganya.

Pada penelitian ini abu sekam padi akan dimodifikasi sehingga dapat difungsikan sebagai fasa diam pada kromatografi kolom. Dengan menggunakan fasa diam berbahan dasar sekam padi, diharapkan mampu mengatasi masalah ketersediaan fasa diam untuk skala besar yang digunakan dalam proses pemisahan dan pemurnian asam lemak. Dengan demikian metode tersebut dapat diterapkan untuk mengisolasi asam lemak dari minyak atsiri yang mengandung campuran beberapa jenis asam lemak jenuh dan tidak jenuh.

Silika dimodifikasi dengan ion perak menggunakan senyawa pengikat, yaitu senyawa yang mempunyai gugus amino.
Gugus amino sangat efektif untuk mengikat ion logam transisi seperti ion perak. Senyawa pengikat tersebut yang sering digunakan adalah amino propil-trimetoksi-silan (APTS). Pada penelitian ini, selain APTS digunakan pula kitosan, dari segi harga jauh lebih rendah dari pada APTS. Hal ini perlu dipertimbangkan karena untuk skala besar diperlukan silika termodifikasi dalam jumlah banyak.

\section{BAHAN DAN METODE Bahan}

Asam lemak yang digunakan adalah asam-asam oleat, stearat dan palmitat spesifikasi p.a dengan masing-masing 2 gram. Senyawa pengikat menggunakan dua jenis senyawa yaitu amino propiltrimetoksisilan (APTS) spesifikasi p.a. dan kitosan yang dilarutkan dalam asam asetat. Sekam padi sebagai sumber silika dan AgNO3 dengan spesifikasi teknis.

Kolom kromatografi yang digunakan mempunyai panjang $23.5 \mathrm{~cm}$, diameter $2 \mathrm{~cm}$. Kolom tersebut berisi fasa diam silika yang telah dimodifikasi, setinggi $20 \mathrm{~cm}$ dari dasar kolom.

\section{Ekstraksi Silika Dari Abu Sekam Padi}

Sekam padi dilebur pada suhu 650 $750^{\circ} \mathrm{C}$, kemudian direndam dalam $\mathrm{HCl} 3 \%$ selama 1 jam, hal ini bertujuan untuk menghilangkan ion logam selain silika. Setelah disaring, residu abu sekam padi diekstraksi menggunakan $\mathrm{NaOH}$ 1N. Hasil ekstraksi dinetralkan dengan asam nitrat $1 \mathrm{~N}$ hingga diperoleh sol silika lalu dicuci mulamula dengan air untuk menghilangkan kelebihan asam dan basa dan terakhir dicuci dengan alcohol untuk menghilangkan air.

\section{Modifikasi Silika}

Ke dalam sol silika ditambahkan larutan kitosan 1\%. Setelah diaduk hingga homogen, ditambahkan $\mathrm{NH} 4 \mathrm{OH}$ hingga sedikit basa. Setelah itu ditambahkan larutan AgNO3 10\% dan dibiarkan selama satu malam. Campuran tersebut disaring dan residu dikeringkan pada suhu $60^{\circ} \mathrm{C}$ dalam keadaan vakum. 
Untuk modifikasi menggunakan APTS, penambahan APTS dilakukan sebelum penambahan asam nitrat $1 \mathrm{~N}$ dan tanpa penambahan $\mathrm{NH} 4 \mathrm{OH}$.

\section{Ion Perak yang Terikat}

Banyaknya ion perak yang terikat pada kedua jenis silika termodifikasi akan mempengaruhi kinerja dari silika tersebut sebagai fasa diam. Untuk mengetahui jumlah ion perak terikat ditentukan melalui titrasi potensiometri terhadap larutan sisa hasil penyaringan pada proses pembuatan silika termodifikasi. Pengujian dengan SEM (Scanning Electron Microscope) untuk mengetahui karakteristik permukaan silika dan EDS ( untuk mengetahui kation-kation yang terikat dalam fasa diam silika.

\section{Metilasi Asam Lemak}

Asam-asam lemak yang akan diuji secara kromatografi terlebih dahulu dilakukan metilasi menggunakan metanol dengan katalis basa dan asam.

\section{Kolom Kromatografi}

Campuran metil ester asam lemak dipisahkan secara kromatografi kolom dengan fasa diam silika termodifikasi. Pelarut atau eluen yang digunakan adalah campuran kloroform dan metanol dengan perbandingan 99: 1 hingga 90:10.

\section{HASILDAN PEMBAHASAN Kemampuan mengikat ion perak}

Dari hasil titrasi potensiometri menunjukkan bahwa kemampuan dalam mengikat ion perak antara silika-APTS dengan silika- kitosan perbedaannya hanya $2 \%$ seperti yang ditunjukkan pada Tabel 1

Tabel 1. Uji pengikatan ion perak $\left(\mathrm{Ag}^{+}\right)$

\begin{tabular}{cc}
\hline $\begin{array}{c}\text { Silika } \\
\text { termodifikasi } \\
\text { oleh }\end{array}$ & $\begin{array}{c}\text { ion Ag yang terikat } \\
(\%)\end{array}$ \\
\hline Kitosan & 87 \\
APTS & 89 \\
\hline
\end{tabular}

Perbedaan tersebut disebabkan pada kitosan gugus amino terikat pada gugus siklik sehingga pembentukan ikatan dengan ion $\mathrm{Ag}$ sedikit mengalami hambatan ruang dibandingkan dengan amino pada APTS. Selanjutnya pada penelitian ini untuk kromatografi kolom menggunakan fasa diam silika yang termodifikasi dengan kitosan.

\section{Karakterisasi dari fasa diam silika- Kitosan-Ag}

Karakterisasi dari silika -kitosan - Ag diuji secara SEM dan EDS. Dari Gambar 1 menunjukkan bahwa silika kitosan berbentuk sekelompok butiran kecil yang menggumpal dengan ukuran partikel bervariasi yaitu 0,046, 0,057 dan $0,057 \mu \mathrm{m}$. Bentuk yang menggumpal menunjukkan bahwa silikakitosan tersebut belum benar-benar kering, masih adanya air yang terjebak. Hal ini akan mempengaruhi kinerja dari silika-kitosan sebagai fasa diam pada pemisahan campuran ester asam lemak.

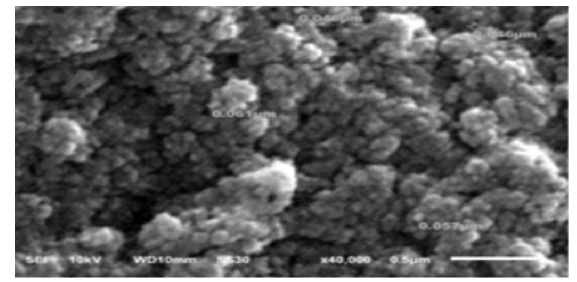

Gambar 1 Penginderaan Si-Kitosan-Ag

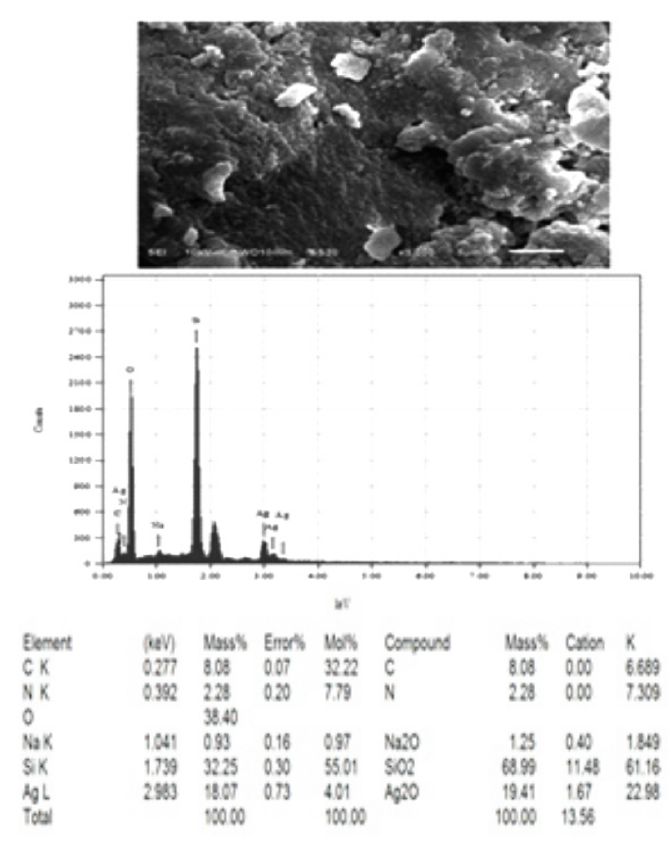

Gambar 2 Uji EDS terhadap Si-Kitosan-Ag 
Gambar 2 menunjukkan permukaan silikakitosan tidak rata sehingga dapat mempengaruhi kemampuan dalam pengikatan ion-ion, seperti ion perak. Sedangkan dari data EDS menunjukkan bahwa kadar $\mathrm{SiO} 2$ sebesar 69\% dan Ag2O mencapai 19\%, sedangkan kitosan mencapai $8 \%$. Kekuatan ion perak yang terikat pada silika-kitosan diuji secara kolom kromatografi berulang kali untuk memisahkan campuran asam lemak.

\section{Metilasi asam lemak}

Metilasi dilakukan dengan menggunakan katalis asam dan basa, Dari hasil analisis kuantitatif dengan gas kromatografi diperoleh hasil sebagai berikut

Tabel 2 Metilasi asam lemak

\begin{tabular}{lcc}
\hline \multirow{2}{*}{ Jenis ester } & \multicolumn{2}{c}{$\%$ berat ester } \\
\cline { 2 - 3 } & Katalis basa & Katalis asam \\
\hline Metil oleat & 0,014 & 64 \\
Metil & 0,008 & 67 \\
palmitat & & \\
Metil stearat & 0,064 & 18 \\
\cline { 2 - 3 }
\end{tabular}

Dari Tabel 2 memperlihatkan bahwa esterifikasi asam lemak menggunakan katalis asam lebih efektif dibandingkan dengan katalis basa, karena ion hidrogen dari katalis asam meningkatkan sifat elektrofilisitas dari asam karboksilat. Sehingga memaksimalkan reaksi esterifikasi.

\section{Kolom kromatografi}

a Campuran metil oleat dan metil palmitat dilewatkan melalui kolom yang berisi silika -kitosan-Ag. Eluen yang digunakan untuk berupa campuran kloroform dan metanol dengan perbandingan yang berbeda. Dari hasil pengujian menggunakan gas kromatografi diperoleh data sebagai berikut

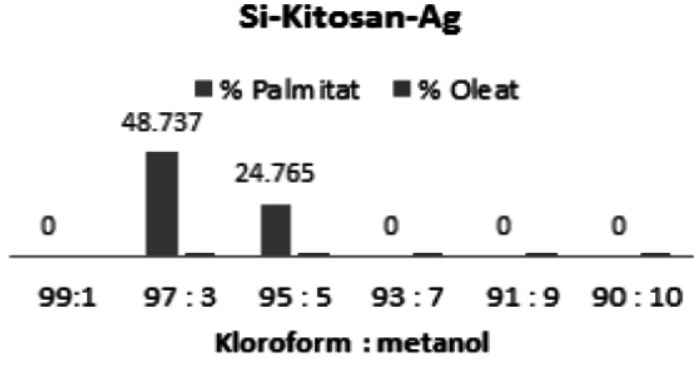

Gambar 3 Pemisahan campuran metil oleat dan metil palmitat

Gambar 3 menunjukkan bahwa metil palmitat terelusi pada eluen kloroform : metanol = 97:3, sedangkan metil oleat tidak terelusi. Hal ini disebabkan senyawa oleat mempunyai ikatan rangkap sehingga akan berinter aksi dengan ion Ag dari fasa diam. Dari Gambar 3 tersebut dapat dikatakan bahwa silika termodifikasi dapat digunakan untuk memisahkan campuran ester asam lemak jenuh dan tak jenuh. Untuk mengeluarkan ester oleat yang terikat dalam fasa diam diperlukan pelarut lain seperti campuran aseton-metanol.

b Campuran metil stearat dan metil palmitat

Campuran metil stearat dan metil palmitat dengan konsentrasi masing-masing 14\% (w/w) dan 17\% (w/w) dilewatkan pada kolom yang berisi si-kitosan-Ag dengan menggunakan eluen campuran kloroformmetanol.

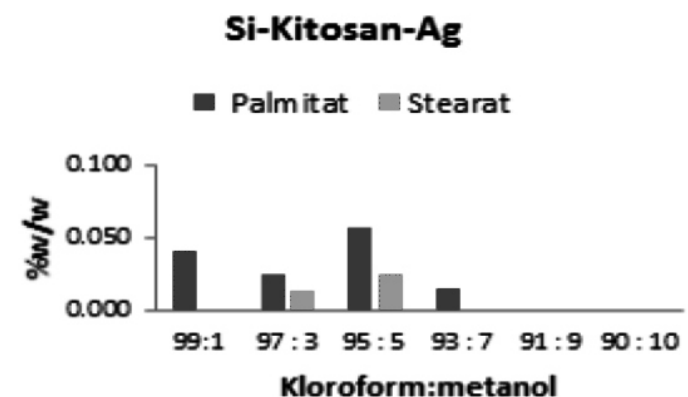

Gambar 4 Pemisahan campuran metil stearat dan metil palmitat dengan menggunakan eluen kloroform-metanol 
Gambar 4 menunjukkan bahwa pelarut campuran kloroform-metanol tidak dapat memisahkan campuran metil palmitat dan metil stearat. Sifat kepolaran kloroform lebih tinggi dibandingkan asam-asam lemak, sehingga kurang sesuai untuk mengelusi asam palmitat dan asam stearat. Oleh karena itu untuk mengelusi campuran asam palmitat dan asam stearat digunakan pelarut yang kepolarannya hampir sama atau dengan kata lain kepolarannya lebih rendah dari kloroform, seperti benzena.

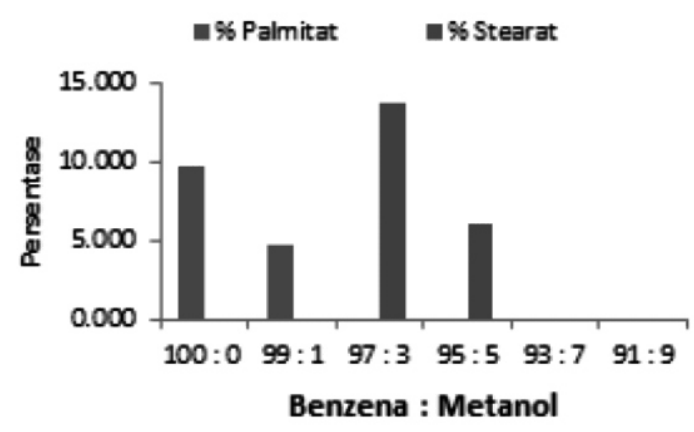

Gambar 5 Pemisahan campuran metil stearat dan metil palmitat.dengan pelarut benzene-metanol

Gambar 5 memperlihatkan pemisahan campuran ester asam lemak jenuh

\section{DAFTAR RUJUKAN}

Boryana Nikolova-Damyanova, B,1992,

Silver ion Chromatography and

Lipids, Advances in Lipid

Methodology-One, Oily Press

Chand,N. dan Jhod, B.D, 2008, Rice Husk

PVC Composites, BioResources 3 (4)

p 1228-1243

Cleary,M.T, dkk, 1982, European patents, $82,305,310.3$

Davinder Mittal, July 1997, Silika from Ash, General article, Resonance

Hasliza Bahruji, 2005, Systhesis of Zeolite Ferrierite From Rice Husk Ash, Characterization and Activity towards Friedel Crafts Acylation for the Formation of $p$ -

Methoxypropiophenone, Thesis, Universiti Teknologi Malaysia Mansaray, K.G,, 1997, Rice Husk, Energy menggunakan pelarut benzene : metanol dengan perbandingan 100:0 dapat mengelusi metil palmitat sedangkan metil stearat dapat dielusi oleh eluan dengan perbandingan 97:3. Dengan demikian pelarut benzene-metanol, dapat memisahkan campuran ester asam lemakjenuh.

\section{Simpulan}

Fasa diam dari kromatografi kolom dibuat dengan memodifikasi silika dari sekam padi. Silika dapat mengikat ion Ag+ jika ada senyawa perantara, seperti kitosan dan APTS. Silika- kitosan dan silika - APTS mampu mengikat ion perak masing-masing $87 \%$ dan $89 \%$. Dari uji karakteristik menggunakan SEM dan EDS, silika-kitosan-Ag mengandung 18\% Ag2O. Sehingga dapat digunakan untuk memisahkan campuran asam lemak yang telah dimetilasi.

Campuran metil palmitat dan metil oleat dapat dipisahkan melalui kromatografi kolom menggunakan fasa diam silikakitosan-Ag dengan eluen kloroform-metanol pada perbandingan 93:7.

Campuran metil palmitat dan metil stearat dapat dipisahkan menggunakan jenis fasa diam yang sama dengan pelarut campuran benzene-metanol 100:0 dan 97:3 .

\section{Source 19}

Nayak, J.P dan Bera, J.,2009, Preparation of Silika Aerogel by Ambient Pressure Drying Process using Rice Husk Ash as Raw Material, Trans. Ind.Ceram.Soc, 68 (2), p 1-4

Nick Zemke, dkk., 2009, Rice Husk Ash,

California Polytechnic State

University

Samantha P.B, dkk, 2011, Production of

Silika Gel From Residual Rice Husk Ash, Quim. Nova, vol.34, No.1, hal.71- 75

Trisno, Iwan, 2011, Penggunaan Abu Sekam

Padi sebagai Adsorben dalam

Pengolahan Air Limbah yang

Mengandung Logam $\mathrm{Cu}$, Litbang,

Kab. Pati

Udayana N.Wanasundara, dkk, 2005, Novel Separation Techniques for Isolation 
Products from Oils and Fats, John Wiley \& Sons.Inc

White, M.F, dkk, 1948, J.Amer, Chem, Soc, $70, \mathrm{p} 42-69$
Anonim,http://en.wikipedia.org/wiki/File:Tra nsesterification_FAME.svg, diakses 25 Oktober 2013 